\title{
Synthesis and electrocatalytic properties of a nickel(II) complex supported by bis(diphenylphosphino)methane
}

Chen-Neng Lin, Shi-Tao Ren, Li-Ping Ye, Cai-Hong Chen*, Shu-Zhong Zhan*

College of Chemistry and Chemical Engineering, South China University of Technology, Guangzhou 510640, China

$\mathrm{NiCl}_{2} \cdot 6 \mathrm{H}_{2} \mathrm{O}$ reacts with bis(diphenylphosphino)methane (dppm) and tetracyanoethylene (TCNE) to afford one unexpected dinuclear nickel complex $\left[\mathrm{Ni}_{2}(\mathrm{dppm})_{2}(\mathrm{CN})_{4}\right] \mathbf{1}$, which have been characterized by electrochemical and spectroscopic methods. Two nickel atoms are doubly bridged by two dppm groups to form an eight membered $\mathrm{Ni}_{2} \mathrm{P}_{4} \mathrm{C}_{2}$ ring. And $\mathbf{1}$ exists the same form in solid as that in liquid. Magnetic studies exhibit that nickel ion is at one low spin state (no free electron), and no magnetic exchange interaction between two nickel ions mediated by dppm groups. In liquid, 1 can electrocatalyze hydrogen generation from acetic acid with a turnover frequency (TOF) of 24 moles of hydrogen per mole of catalyst per hour at an overpotential (OP) of $941.6 \mathrm{mV}$ (in DMF).

Keywords: Dinuclear nickel complex; molecular electrocatalyst; proton reduction; hydrogen evolution.

\footnotetext{
* Corresponding author. Fax: +86-20-87112906;

E-mail:shzhzhan@scut.edu.cn
} 
Hydrogen is one ideal energy in the future, because of its numerous advantages, such as recyclability and pollution-free use [1]. Water is the only waste-free electron-source substrate that could sustain the scale of the process required to supply our energy demands. Thus water splitting is an important and simple method for hydrogen production, which can be used as a cheap, green fuel [2]. The generation of hydrogen from electrochemical reduction of a proton source, such as weak acid and water, represents an attractive approach for storing the electrical energy transiently produced by renewable energy sources [3]. In Nature, hydrogenase enzymes are very efficient catalysts for reductive generation of dihydrogen [4]. However, enzymes are difficult to adapt for commercial applications and their stability is often limited outside of their native environment [5]. A challenging method for overcoming this problem would be to develop efficient, and stable catalysts that employ abundant, and as a consequence cheap, metals such as iron, cobalt, nickel, and copper. Therefore, many research groups, including ours, have designed molecular catalysts by employing the abundant metals, and several complexes of nickel [6,7], cobalt [8-12] and copper [13-16] have been developed as electrocatalysts for the reduction of proton or water to form $\mathrm{H}_{2}$. As a continue work on the design of molecular catalysts, reported here is an electrocatalyst based on a dinuclear nickel complex, $\left[\mathrm{Ni}_{2}(\mathrm{dppm})_{2}(\mathrm{CN})_{4}\right] \mathbf{1}$ for hydrogen evolution from acetic acid.

Typically, the reaction of TCNE with transition metal centers led to di-, tri- or tetranuclear nitrile-bonded $\sigma$ compounds, to $\pi$ compounds with side-on coordination. However, the reaction of $\mathrm{NiCl}_{2} \cdot 6 \mathrm{H}_{2} \mathrm{O}$, dppm and TCNE provides one unprecedented 
complex $\left[\mathrm{Ni}_{2}(\mathrm{dppm})_{2}(\mathrm{CN})_{4}\right] \mathbf{1}$ [17], which cannot be obtained by the reaction of $\mathrm{NiCl}_{2} \cdot 6 \mathrm{H}_{2} \mathrm{O}$, dppm, and $\mathrm{KCN}$. The infrared spectrum of $\mathbf{1}$ shows two $v(\mathrm{CN})$ stretching at 2124 and $2095 \mathrm{~cm}^{-1}$ at higher energies than that of the free $\mathrm{CN}^{-}$ion (2080 $\mathrm{cm}^{-1}$ ), assigning to the cyanide mode in complex $\mathbf{1}$ (Fig. S1). Magnetic measurement shows that nickel ion is at one low spin state $(S=0)$, and no magnetic exchange interaction between two nickel ions mediated by dppm groups.

Complex 1 . $2 \mathrm{MeOH}$ crystallizes in a monoclinic system, space group P2(1)/n with two formula units present per unit cell. As shown in Fig. 1, each nickel atom exhibits square-planar geometry with two trans-cyano groups and two trans-P atoms from bridging dppm molecules. And the two $\mathrm{NiP}_{2}(\mathrm{CN})_{2}$ units in the dimer are in normal face-to-face orientation, with the $\mathrm{Ni} \cdots \mathrm{Ni}$ separation of $3.258 \AA$. However, it is longer than the $\mathrm{Ni} \cdots \mathrm{Ni}$ distances of $2.957(1) \AA$ in $\left[\mathrm{Ni}_{2}(\mathrm{dcpm})_{2}(\mathrm{CN})_{4}\right](\mathrm{dcpm}$ : bis(dicyclohexylphosphino)methane) [18], 3.209(8) $\AA$ in $\left[\mathrm{Ni}_{2}(\mathrm{dmpm})_{2}(\mathrm{CN})_{4}\right](\mathrm{dmpm}$ : bis(dimethylphosphino)methane) [18], and 2.542(2) $\AA$ in $\left[\mathrm{HgNi}_{4}(\mathrm{dppm})_{2}\right]$ [19]. The $\mathrm{P}-\mathrm{Ni}-\mathrm{P}$ angle is $175.93(6)^{\circ}$ and the $\mathrm{C}-\mathrm{Ni}-\mathrm{C}$ angle is $161.5(2)^{\circ}$. The Ni-C distances are 1.954(5) and 1.854(6) $\AA$, respectively. And the Ni-P distances are 2.2087(13) and 2.2174(13) A, respectively.

The stability of the title complex in liquid has been examined using multiple physicochemical methods. First, in methanol or N,N-dimethylformamide (DMF), $\left[\mathrm{Ni}_{2}(\mathrm{dppm})_{2}(\mathrm{CN})_{4}\right] \mathbf{1}$ exhibits the same state as that in solid, which are in agreement with results from ESI-MS measurements which exhibit one ion at a mass-to-charge ratio $(\mathrm{m} / \mathrm{z})$ of 1011.1116 in both methanol and DMF (Figs. S2-S3), with the mass and 
isotope distribution pattern corresponding to that of $\left[\mathrm{Ni}_{2}(\mathrm{dppm})_{2}(\mathrm{CN})_{4}-\mathrm{Na}\right]^{+}$. Second, the UV/Vis spectrum of $\mathbf{1}$ in DMF shows an absorption peak at $506 \mathrm{~nm}$ (Fig. S4), which corresponds to a ligand-metal-charge-transition (LMCT) between the ligands and nickel ion. From Fig. S4, the intensity of the absorption band at $506 \mathrm{~nm}$ slightly increases with increasing the temperature from 298 to $353 \mathrm{~K}$, but the peak position does not move, indicating this complex is stable under these conditions. Third, the following electrochemical studies.

Fig. 1. Molecular structure of complex 1.

To study the electrochemical behavior complex 1, cyclic voltammogram (CV) was measured in DMF with $0.10 \mathrm{M}\left[(\mathrm{n}-\mathrm{Bu})_{4} \mathrm{~N}\right] \mathrm{ClO}_{4}$ as the supporting electrolyte. From Fig. 2, 1 shows a quasi-reversible redox couple at $-0.95 \mathrm{~V}$ versus $\mathrm{Ag} / \mathrm{AgNO}_{3}$, which can be assigned to that of $\mathrm{Ni}^{\mathrm{iI}} / \mathrm{Ni}^{\mathrm{I}}$. To investigate the effect of the temperatures of media on the electrochemical behaviors of complex $1, \mathrm{CVs}$ were measured in the range 303 to $348 \mathrm{~K}$. According to Fig. S5, the current strength slightly increase near $-0.96 \mathrm{~V}$ with varying temperature from 303 to $348 \mathrm{~K}$, suggesting that complex $\mathbf{1}$ is stable in above system. From Fig. S6, the current response of the redox event at -0.96 $\mathrm{V}$ shows linear dependence on the square root of the scan rate, indicating a diffusion-controlled process, with the electrochemically active species freely diffusing in solution [20]. According to Fig. S7, the impedance is small due to homogeneous catalytic system. This is consistent with the above electrochemical behavior.

From Fig. 3 it can be seen that the catalytic currents near $-0.96 \mathrm{~V}$ increase with 
increasing acetic acid concentration from 0.0 to $19.61 \mathrm{mM}$, showing that hydrogen generation electrocatalyzed by 1 requires the reduction of $\mathrm{Ni}(\mathrm{II})$ to $\mathrm{Ni}(\mathrm{I})$ and protonation [21]. Interestingly, with the acetic acid concentration increase from 0.0 to $19.61 \mathrm{mM}$, the potential of $\mathrm{Ni}^{\mathrm{II}} / \mathrm{Ni}^{\mathrm{I}}$ moves positive about $40 \mathrm{mV}$ from $-0.96 \mathrm{~V}$ to -0.92 $\mathrm{V}$, and the onset of the catalytic wave also moves positive about $330 \mathrm{mV}$ from -0.65 to $-0.32 \mathrm{~V}$ compared to that in the absence of $\mathbf{1}$. Based on the above observations and literature precedent [22,23], we postulate the catalytic cycle depicted in Scheme 1 for the generation of hydrogen from acid mediated by 1 . Two-electron reduction of $\left[\mathrm{Ni}_{2}^{\mathrm{II}}(\mathrm{dppm})_{2}(\mathrm{CN})_{4}\right]$ provides one species, $\left[\mathrm{Ni}_{2}{ }_{2}(\mathrm{dppm})_{2}(\mathrm{CN})_{4}\right]^{2-}$. Addition of proton (acetic acid) affords the intermediate species, $\left[\left(\mathrm{Ni}^{\mathrm{III}}-\mathrm{H}\right)_{2}(\mathrm{dppm})_{2}(\mathrm{CN})_{4}\right]$. Further two-electron reduction gives one reactive $\left[\left(\mathrm{Ni}^{\mathrm{II}}-\mathrm{H}\right)_{2}(\mathrm{dppm})_{2}(\mathrm{CN})_{4}\right]^{2-}$, then generates $\mathrm{H}_{2}$ and gives rise to a cycle. More detailed mechanistic studies are under investigation.

Fig. 3. CVs of a $1.00 \mathrm{mM}$ solution of complex 1, with varying concentration of acetic acid in DMF. Conditions: $0.10 \mathrm{M}\left[\mathrm{n}-\mathrm{Bu}_{4} \mathrm{~N}\right] \mathrm{ClO}_{4}$ as supporting electrolyte, scan rate: $100 \mathrm{mV} / \mathrm{s}$, glassy carbon working electrode (1 mm diameter), Pt counter electrode, $\mathrm{Ag} / \mathrm{AgNO}_{3}$ reference electrode, Fc internal standard (*). 

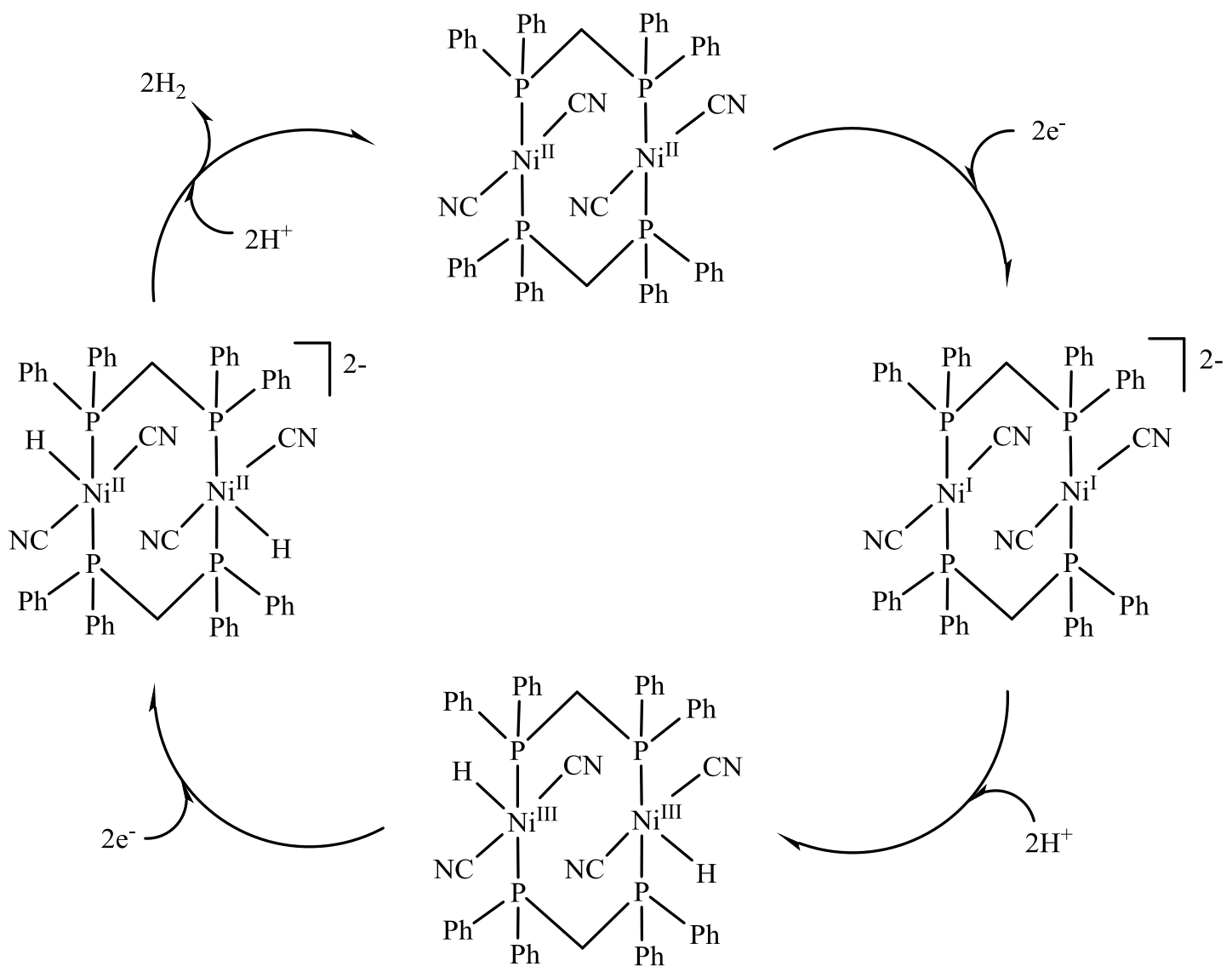

Scheme 1 The possible catalytic mechanism for proton reduction by 1 .

To testify the catalytic activities of this nickel complex, bulk electrolysis by complex 1 was conducted in DMF solution with acetic acid at variable applied potential using a glassy carbon plate electrode in a double-compartment cell. According to Fig. $4 \mathrm{a}$, when the applied potential was $-1.45 \mathrm{~V}$ versus $\mathrm{Ag} / \mathrm{AgNO}_{3}$, the maximum charge reaches $24 \mathrm{mC}$ during 2 min of electrolysis, with accompanying evolution of a gas, which was confirmed as $\mathrm{H}_{2}$ by gas chromatography. According to Fig. S8, $\sim 0.03 \mathrm{~mL}$ of $\mathrm{H}_{2}$ was produced over an electrolysis period of $2 \mathrm{~h}$ under $-1.45 \mathrm{~V}$ versus $\mathrm{Ag} / \mathrm{AgNO}_{3}$. And a controlled-potential electrolysis (CPE) experiment under the same potential without 1 gives a charge of only $8 \mathrm{mC}$ (Fig. 4b), showing that this 
nickel complex does indeed serve as effective hydrogen producer under such conditions. Assuming every catalyst molecule was distributed only on the electrode surface and every electron was used for the reduction of protons, from Equations (1) [12] and (2) [24], we calculated the TOF for the catalysts as reaching a maximum of 24 moles of hydrogen per mole of catalyst per hour at an overpotential of $941.6 \mathrm{mV}$ (Fig. S9).

$\mathrm{TOF}=\Delta C /\left(\mathrm{F}^{*} n_{1}{ }^{*} n_{2} * t\right)$

Overpotential $=$ Applied potential $-\mathrm{E}^{\odot} \mathrm{HA}$

$$
=\text { Applied potential }-\left(\mathrm{E}^{\odot}{ }_{\mathrm{H}}{ }^{+}-(2.303 R T / F) \mathrm{p} K_{a \mathrm{HA}}\right)
$$

Where, $\Delta C$ is the charge from the catalyst solution during CPE minus the charge from solution without catalyst during $\mathrm{CPE}$; $\mathrm{F}$ is Faraday's constant, $n_{1}$ is the number of moles of electrons required to generate one mole of $\mathrm{H}_{2}, n_{2}$ is the number of moles of catalyst in solution, and $\mathrm{t}$ is the duration of electrolysis.

Fig. 4. (a) Charge buildup versus time from electrolysis of a $2.025 \mu \mathrm{M}$ complex 1 in $\operatorname{DMF}\left(0.10 \mathrm{M}\left[\mathrm{n}-\mathrm{Bu}_{4} \mathrm{~N}\right] \mathrm{ClO}_{4}\right)$ under various applied potentials. All data have been deducted blank. (b) Charge buildup versus time from electrolysis of a $0.10 \mathrm{M}$ $\left[\mathrm{n}-\mathrm{Bu}_{4} \mathrm{~N}\right] \mathrm{ClO}_{4}$ solution in DMF under $-1.45 \mathrm{~V}$ versus $\mathrm{Ag} / \mathrm{AgNO}_{3}$.

In this paper, we have described one nickel(II) complex, that is obtained from the reaction of the simple nickel salt, dppm and TCNE, which has been characterized by electrochemical and spectroscopic methods. This sample of complex $\mathbf{1}$ can electrocatalyze hydrogen generation from acetic acid. Our ongoing efforts are focused on modifying the ligand to give related water-soluble complexes with higher activity 
for further functional studies, with an emphasis on chemistry relevant to sustainable energy cycles.

\section{Acknowledgements}

This work was supported by the National Science Foundation of China (No. 20971045 and 21271073).

\section{References}

[1] M. G. Walter, E. L. Warren, J. R. McKone, S. W. Boettcher, Q. X. Mi, E. A. Santori, N. S. Lewis, Chem. Rev. 110 (2010) $6446-6473$.

[2] A. J. Esswein, D. G. Nocera, Chem. Rev. 107 (2007) 4022.

[3] H. B. Gray, Nat. Chem. 1 (2009) 7-7.

[4] J. W. Tye, M. B. Hall, M. Y. Darensbourg, Proc. Nat. Acad. Sci. USA. 102 (2005) 16911-16912.

[5] T. Goris, A. F. Wait, M. Saggu, J. Fritsch, N. Heidary, M. Stein, I. Zebger, F. Lendzian, F. A. Armstrong, B. Friedrich, O. Lenz, Nat. Chem. Biol. 7 (2011) $310-318$.

[6] M. L. Helm, M. P. Stewart, R. M. Bullock, M. R. DuBois, D. L. DuBois, Science 333 (2011) 863-866.

[7] J. P. Cao, T. Fang, L. Z. Fu, L. L. Zhou, S. Z. Zhan, Int. J. Hydrogen Energy 39 (2014) 10980-10986. 
[8] Y. Sun, J. P. Bigi, N. A. Piro, M. L. Tang, J. R. Long, C. J. Chang, J. Am. Chem. Soc. 133 (2011) 9212-9215

[9] L. Z. Fu, L. L. Zhou, L. Z. Tang, Y. X. Zhang, S. Z. Zhan, J. Power Sources 280 (2015) 453-458.

[10] B. D. Stubbert, J. C. Peters, H. B. Gray, J. Am. Chem. Soc. 133 (2011) $18070-18073$.

[11] W. M. Singh, T. Baine, S. Kudo, S. Tian, X. A. N. Ma, H. Zhou, N. J. DeYonker, T. C. Pham, J. C. Bollinger, G. L. Baker, B. Yan, C. E. Webster, X. Zhao, Angew. Chem. Int. Ed. 51 (2012) 5941-5944.

[12] L. Tong, R. Zong, R. P. Thummel, J. Am. Chem. Soc. 136 (2014) 4881-4884.

[13] T. Fang, L. Z. Fu, L. L. Zhou, S. Z. Zhan, Electrochimica Acta 161 (2015) 388-394.

[14] J. P. Cao, T. Fang, L. Z. Fu, L. L. Zhou, S. Z. Zhan, Int. J. Hydrogen Energy 39 (2014) 13972-13978.

[15] L. L. Zhou, T. Fang, J. P. Cao, Z. Zhu, X. Su, S. Z. Zhan, J. Power Sources 273 (2015) 298-304.

[16] P. Zhang, M. Wang, Y. Yang, T. Yao, L. Sun, Angew. Chem. Int. Ed. 53 (2014) 13803-13807.

[17] Synthesis of $\left[\mathrm{Ni}_{2}(\mathrm{dppm})_{2}(\mathrm{CN})_{4}\right] \mathbf{1}$

After addition of TCNE $(0.13 \mathrm{~g}, 1.0 \mathrm{mmol})$ in dichloromethane $(20 \mathrm{~mL})$ to a solution containing $\mathrm{NiCl}_{2} \cdot 6 \mathrm{H}_{2} \mathrm{O}(0.237 \mathrm{~g}, 1.0 \mathrm{mmol})$ and $\mathrm{dppm}(0.385 \mathrm{~g}, 1.0 \mathrm{mmol})$ in methanol $(20 \mathrm{~mL})$, the mixture was stirred for $2 \mathrm{~h}$ at room temperature. Then the color 
turned from green to deep green. Single crystals were obtained from the filtrate which was allowed to stand at room temperature for several days, collected by filtration, and dried in vacuo $(0.62 \mathrm{~g}, 63 \%)$. Calcd for $\mathrm{C}_{54} \mathrm{H}_{44} \mathrm{Ni}_{2} \mathrm{~N}_{4} \mathrm{P}_{4}: \mathrm{C}, 65.49 ; \mathrm{H} 4.49 ; \mathrm{N}, 5.66$. Found: C, 65.28; H, 4.51; N, 5.63. IR bands (KBr pellet, $\left.\mathrm{cm}^{-1}\right): v=2124,2095$. [18] B.-H. Xia, C.-M. Che, D. L. Phillips, K.-H. Leung, K.-K. Cheung, Inorg. Chem. 41 (2002) 3866-3875.

[19] J. Gong, J. Huang, P. E. Fanwick, C. P. Kubiak, Angew. Chem. 102 (1990) 407-408.

[20] K. C. Huang, R. J. White, J. Am. Chem. Soc. 135 (2013) 12808-12817.

[21] H. I. Karunadasa, C. J. Chang, J. R. Long, Nature 464 (2010) 1329-1333.

[22] J.-P. Cao, T. Fang, L.-Z. Fu, L.-L. Zhou, S.-Z. Zhan, Int. J. Hydrogen Energy 39 (2014) 10980-10986.

[23] J. T. Muckermann, E. Fujita, Chem. Commun. 47 (2011) 12456-12458.

[24] G. A. N. Felton, R. S. Glass, D. L. Lichtenberger, D. H. Evans, Inorg. Chem. 45 (2006) $9181-9184$. 


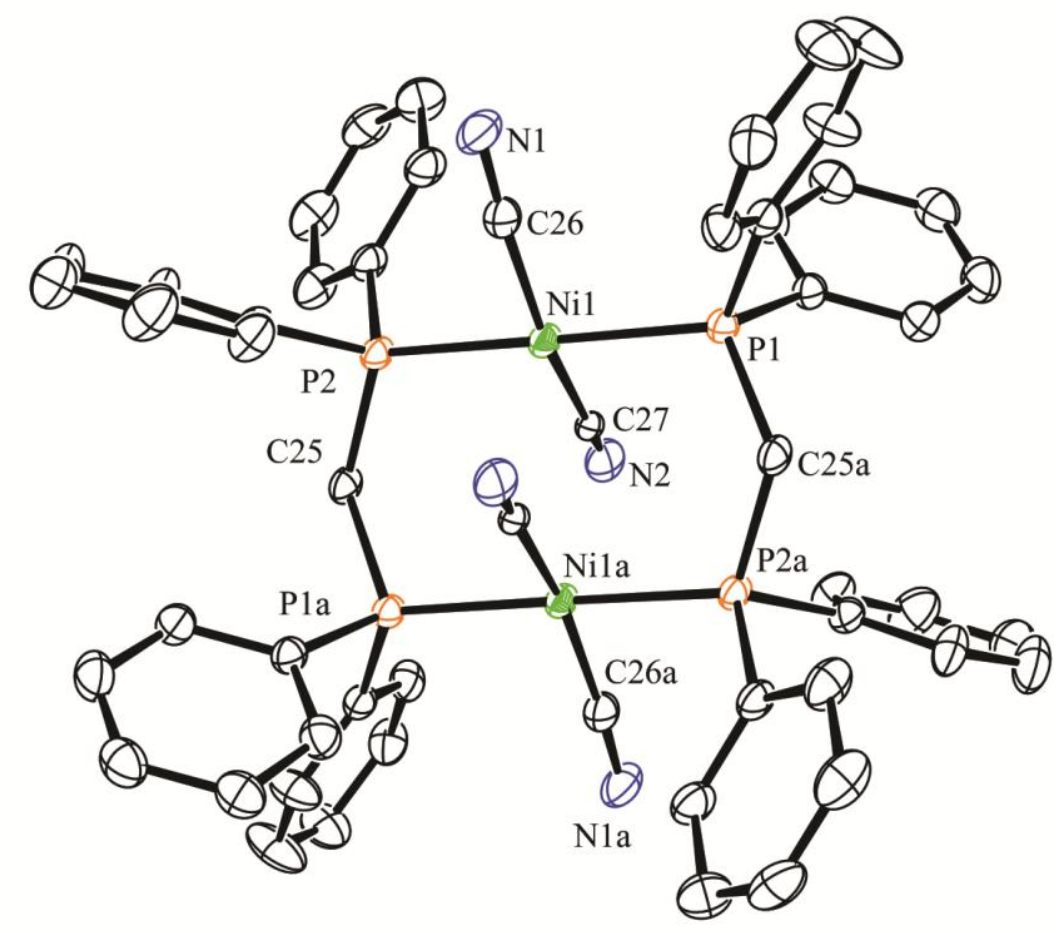

Fig. 1. Molecular structure of complex 1 


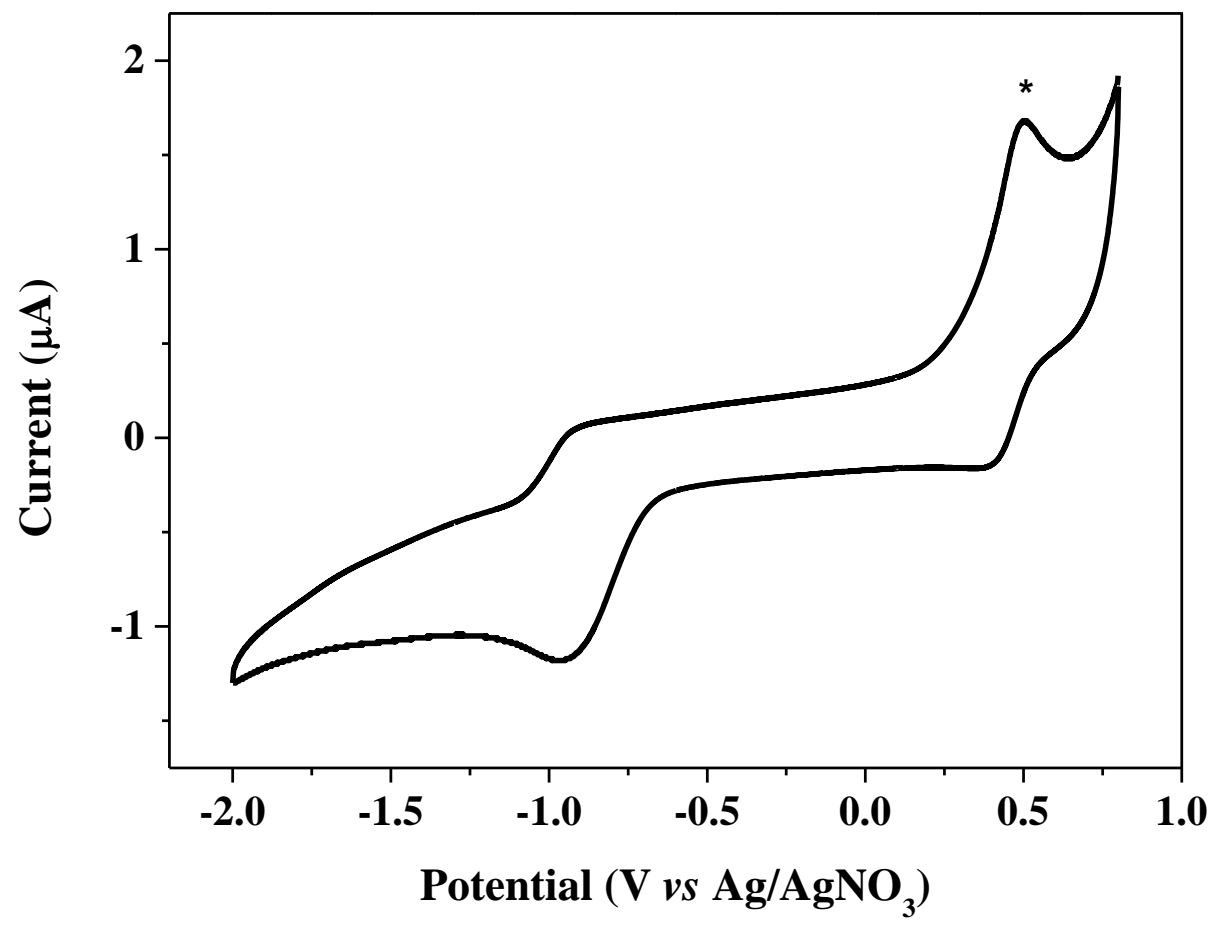

Fig. 2. $\mathrm{CV}$ of $1.00 \mathrm{mM}$ complex 1 in DMF. Conditions: room temperature, $0.10 \mathrm{M}$ $\left[\mathrm{n}-\mathrm{Bu}_{4} \mathrm{~N}\right] \mathrm{ClO}_{4}$ as supporting electrolyte, scan rate: $100 \mathrm{mV} / \mathrm{s}$, glassy carbon working electrode (1 mm diameter), Pt counter electrode, $\mathrm{Ag} / \mathrm{AgNO}_{3}$ reference electrode. Ferrocene internal standard (*). 


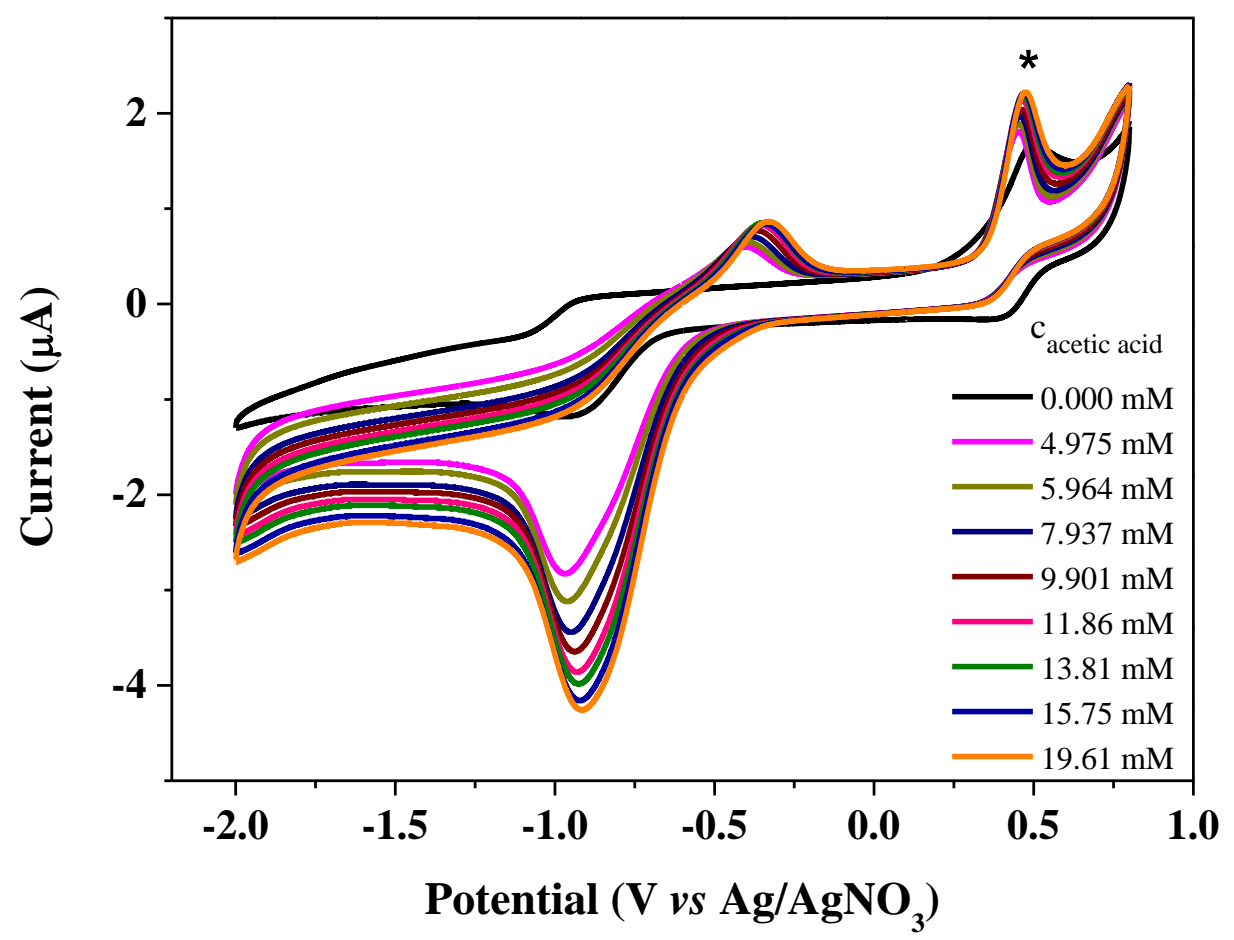

Fig. 3. CVs of a $1.00 \mathrm{mM}$ solution of complex 1, with varying concentration of acetic acid in DMF. Conditions: $0.10 \mathrm{M}\left[\mathrm{n}-\mathrm{Bu}_{4} \mathrm{~N}\right] \mathrm{ClO}_{4}$ as supporting electrolyte, scan rate: $100 \mathrm{mV} / \mathrm{s}$, glassy carbon working electrode (1 mm diameter), Pt counter electrode, $\mathrm{Ag} / \mathrm{AgNO}_{3}$ reference electrode, Fc internal standard (*). 

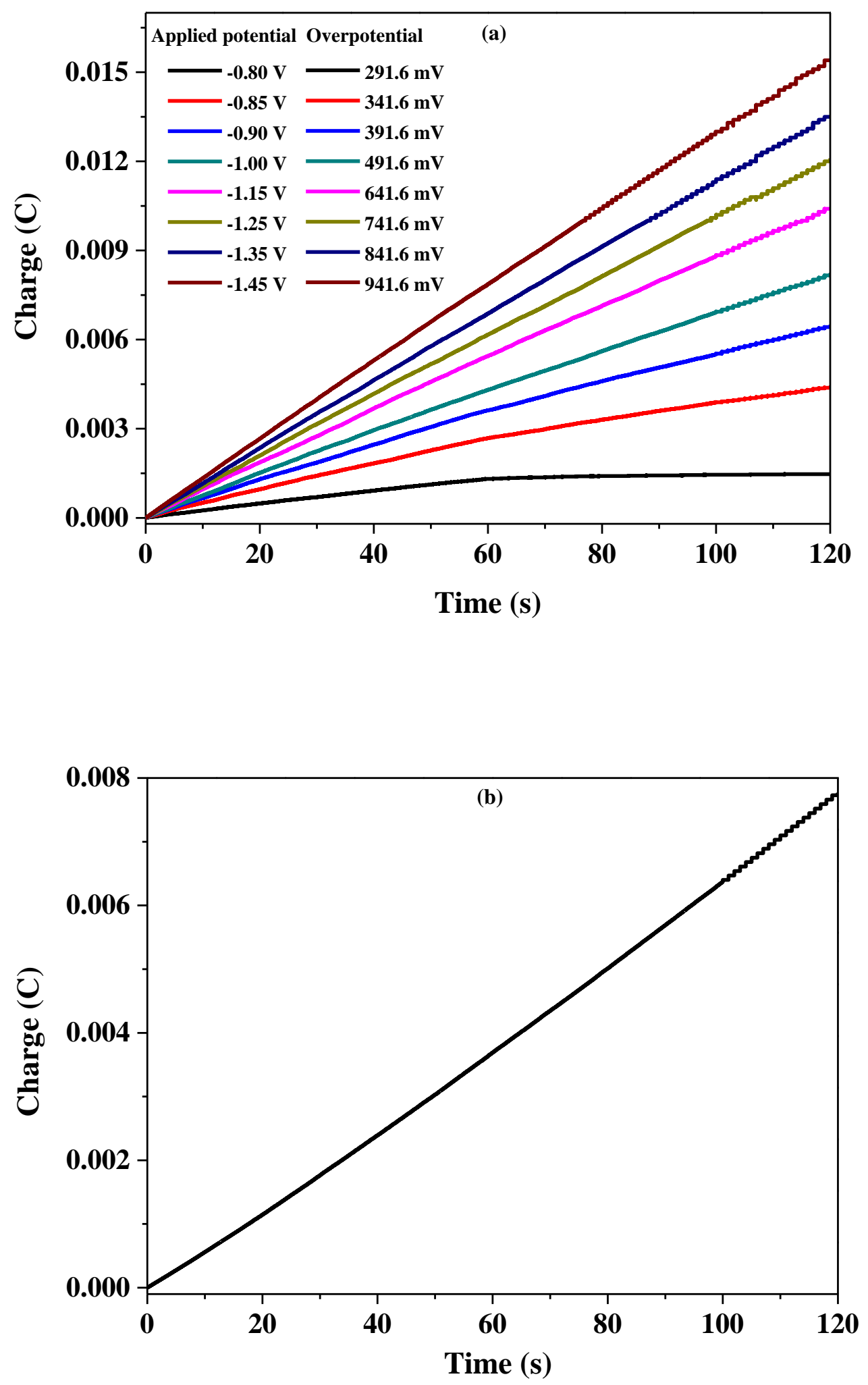

Fig. 4. (a) Charge buildup versus time from electrolysis of a $2.025 \mu \mathrm{M}$ complex 1 in DMF $\left(0.10 \mathrm{M}\left[\mathrm{n}-\mathrm{Bu}_{4} \mathrm{~N}\right] \mathrm{ClO}_{4}\right)$ under various applied potentials. All data have 
been deducted blank. (b) Charge buildup versus time from electrolysis of a $0.10 \mathrm{M}$ $\left[\mathrm{n}-\mathrm{Bu}_{4} \mathrm{~N}\right] \mathrm{ClO}_{4}$ solution in DMF under $-1.45 \mathrm{~V}$ versus $\mathrm{Ag} / \mathrm{AgNO}_{3}$. 


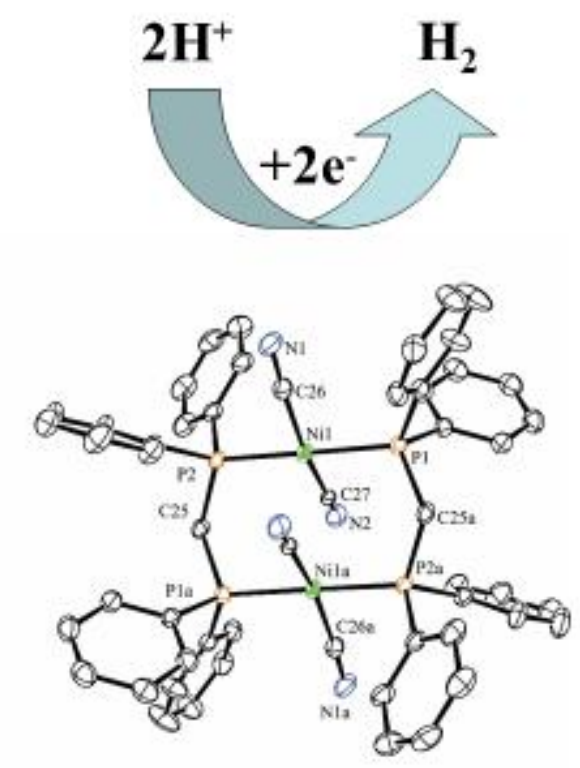


A new molecular electrocatalyst based on nickel complex $\left[\mathrm{Ni}_{2}(\mathrm{dppm})_{2}(\mathrm{CN})_{4}\right] \mathbf{1}$ is formed by the reaction of $\mathrm{NiCl}_{2} \cdot 6 \mathrm{H}_{2} \mathrm{O}$, bis(diphenylphosphino)methane (dppm) and tetracyanoethylene (TCNE) for hydrogen evolution from acetic acid. 